\title{
From The Geneva Papers on Risk and Insurance to The Geneva Risk and Insurance Review
}

\author{
Henri Loubergé \\ Geneva School of Economics and Management, University of Geneva, Uni Mail, 40 Blvd du Pont d'Arve, \\ 1211 Geneva 4, Switzerland. \\ E-mail: henri.louberge@unige.ch
}

The Geneva Risk and Insurance Review celebrates in 2016 its $40^{\text {th }}$ year of existence. Yes. But it must be recalled that about half of these 40 years occurred under a different nameThe Geneva Papers on Risk and Insurance. For a long time, the fate of the journal was very closely linked to the development of "The Geneva Association".

The Geneva Risk and Insurance Review (2015) 40, 97-101. doi:10.1057/grir.2015.2

Keywords: risk; uncertainty; insurance; risk management

Article accepted 11 June 2015

The International Association for the Study of Insurance Economics-better known as "The Geneva Association"-was created in 1973 by a group of about 20 leading European insurers. ${ }^{1}$ Their objective was to provide a link between insurance and economic research. For this reason, they hired as Secretary General a young economist from the Battelle Research Institute in Geneva, Dr. Orio Giarini, and they invited a famous French economist, Professor Raymond Barre, as the first chairman of The Geneva Association. Raymond Barre, a professor at the University of Paris, was well-known by all French students in economics at that time for his best-seller handbook "Economie Politique". He was also more generally known for having been called in 1967 by President Charles de Gaulle as one of the two French representatives at the European Economic Commission in Brussels, the board of the original European Union with six member states. He maintained this position, as Vice-President of the Commission, until 1973, working in particular on the coordination of monetary policies and the plans for a European currency union. He may be considered one of the founding fathers of the euro. After having

\footnotetext{
${ }^{1}$ Most notably, among them, the eight members of the original board: Fabio Padoa (Assicurazioni Generali, Trieste), Georges Martin (Royale Belge, Brussels), Julius Neave (Mercantile and General, London), Bernard Pagezy (Groupe de Paris, Paris), Reimer Schmidt (Aachener und Münchener, Aachen), M.H. Urbanski (Erste Allgemeine, Vienna), M.J. Van der Velden (Nationale Nederlanden, Den Haag) and Heinz Vischer (Swiss Re, Zurich).
} 
accomplished his mandate in Brussels, he returned to the University of Paris. Soon after, he started his mandate as chairman of The Geneva Association. ${ }^{2}$

The first steps of Raymond Barre and Orio Giarini at the head of the Association were motivated by the desire to ensure the credibility of The Geneva Association among its partners in the economy. They maintained that risk and the growing importance of risk in modern societies were the roots for the economic relevance of insurance institutions and for their sustained performance as providers of economic security. For this reason, they developed contacts with economists in two directions: first, by commissioning contract research on risks, on corporate risk management and on their implications for the future of the insurance industry; and secondly, by creating links with academic scholars focusing on the study of risk, uncertainty and insurance. These actions led to the creation of the European Group of Risk and Insurance Economists (EGRIE), with a first meeting in Geneva in 1974, and to the decision to create a publication where results from contract research would be made available. Initially, this publication was not intended to appear regularly. As far as I remember, Raymond Barre was inspired by two U.S. publications which appeared irregularly and were famous at that time among economists specialising in international economics: the Princeton Essays and Princeton Studies in International Finance. These two publications were usually called Princeton Papers in International Finance. Hence, the name of the new publication appearing under the auspices of The Geneva Association: The Geneva Papers on Risk and Insurance.

The first issue of The Geneva Papers appeared in January 1976 with an introduction by Raymond Barre. It presented "A model for measuring the impacts of inflation on motor insurance business" developed by two economists at the Battelle Research Centre in Geneva, Jean-Marc Belloy and André Gabus. The two authors had designed a simulation model, called GIM (Geneva Insurance Model) that could be tailored to the needs of specific insurers "to improve their understanding of the effects of inflation in their business operations". 3 The second issue was published in August 1976. It focused on risk management, with four papers, one of them, in particular, reporting on "A survey of the practice of risk management in West Europe companies" conducted by Roy Damary at Giraconsult with the sponsorship of The Geneva Association. This study, which presented insurance as one of the risk management tools available to corporate risk managers, was not well-received by some members of the Association. But its publication in The Geneva Papers was important to strengthen the credibility of The Geneva Association as a trustworthy research sponsor-not as a lobbying institution.

\footnotetext{
${ }^{2}$ Raymond Barre had to leave the chair of The Geneva Association in 1976, being called by President Valery Giscard D'Estaing as Minister of Foreign Trade in the French government. Later in the same year he was appointed Prime Minister of France, a position he maintained until 1981 and the election of a new French president, François Mitterand.

${ }^{3}$ Inflation was quite high and accelerating in the 1970 s.
} 
The third and fourth issues of The Geneva Papers were also entirely devoted to specific themes: No. 3, published in French, dealt with a forecast of economic losses due to the use of computers in Europe at the 1988 horizon; No. 4, published in January 1977, presented the English version of a report I had produced in 1976 at the request of Orio Giarini on "The teaching of risk and insurance economics in Europe". 4

However, 1977 marked a first milestone in the development of The Geneva Papers. Issues 5 (February 1977) and 6 (October 1977) were not devoted to specific themes, but to the publication of papers presented at the EGRIE meetings. Their title was "Essays in the Economic Theory of Risk and Insurance". Issue No. 5 presented papers by Dieter Farny, Christian Ferry and Jean-Jacques Rosa. Issue No. 6 papers by Karl Borch, Gerry Dickinson, Orio Giarini, Elmar Helten and Lutgart Van den Berghe.

The year 1978 was also noteworthy for several reasons. First, The Geneva Papers became a regular publication with quarterly issues. Second, they became a listed publication with copyrights, an editor (Orio Giarini) and an assistant editor (myself). Third, we started to welcome unsolicited manuscripts. Three unsolicited papers already appeared in No. 11 (January 1979). An ad hoc editorial board was formed that same year to select the accepted papers. ${ }^{5}$ The first refereed article to appear in The Geneva Papers was "The demand for non-life insurance: A consumption oriented model", by Antonio Falciglia (No. 17, June 1980). Fourth, one issue per year was devoted to the publication of materials presented on the occasion of "The Annual Lecture of The Geneva Association", a new initiative that consisted in the organisation of a public conference by a renowned economist with major contributions in the field of risk and uncertainty. Kenneth Arrow inaugurated the series, with a lecture on "Risk allocation and information: some recent developments" consecutively at the London School of Economics and at the University of Geneva. The lecture appeared as No. 8 of The Geneva Papers in June 1978. The following lectures were delivered by Jacques Dreze (published 1979), Martin Feldstein (1980), Karl Borch (1981), Joseph Stiglitz (1982), Raymond Barre(1983), Walter Weisskopf (1983), Edmond Malinvaud (1984), etc. until 1996 with a last one (to my knowledge) by Howard Kunreuther.

From 1978 on, and until 1990, the format of The Geneva Papers remained more or less the same: four issues per year, one for the publication of the Annual Lecture, one for papers on the economics of risk and insurance, two for more practice-oriented papers regrouped under a specific theme such as: Risk Management, Social Security, Solvency, etc. This was formalised in 1982, where the journal was presented as "A Quarterly Journal on Risk, Uncertainty and Insurance Economics" and earned a volume number (Vol. 7 for 1982). The refereeing process became more systematic, not only for unsolicited manuscripts, but also for papers presented at the EGRIE meetings.

\footnotetext{
${ }^{4}$ This report, originally in French (1976), also appeared in German in 1977.

${ }^{5}$ Carla Angela, Karl Borch, Robert Carter, Louis Eeckhoudt, Eugenio Prieto and Jean-Jacques Rosa formed this first editorial board. Referees also started to be increasingly used.
} 
100

By the end of the 1980s, with an extraordinary expansion in scientific research and in the number of refereed journals focusing on economics and finance, it became clear that The Geneva Papers needed a redefinition to maintain its status as the European journal publishing research on the economics of risk, uncertainty and insurance. In discussion with Orio Giarini and colleagues from EGRIE, more particularly Harris Schlesinger, it became clear that it would be rational to split the journal in two publications: one more practice-oriented, the other more theoryoriented. The move took place in 1990, where The Geneva Papers appeared under two different names with different colours and a more focused objective. The Geneva Papers on Risk and Insurance-Issues and Practice, under the editorship of Orio Giarini, kept the traditional orange colour and the original numbering, starting with No. 54 in January 1990. It intended to publish the results from more practice-oriented research or conference papers regrouped around a common theme. ${ }^{6}$ The Geneva Papers on Risk and Insurance Theory kept the original volume numbering but adopted a different colour (beige and green), two editors (Harris Schlesinger and me) and a board of 16 associate editors. ${ }^{7}$ The focus of the journal was laid down in the Editors' note in the first issue of the new journal:

The main focus of The Geneva Papers on Risk and Insurance Theory is the economics of risk and insurance. The decade of the 1980s saw tremendous advances in "state of the art" risk and insurance theory: the defining of "downside risk"; an extension of risk aversion to multiple risks; the evolution of "non-expected utility"; models of insurance purchasing with background risk; method for "risk-neutral" pricing of assets; models of insurance firms based on diffusion processes; and countless other noteworthy advances. As we enter a new decade, we can only wonder at the many advances that lie ahead.

Because it was more focused, the new publication was intended to appear in volumes of two issues only. Our original intention as editors was to publish one issue with refereed papers-including papers submitted after a presentation at the EGRIE meeting, and one Special issue per year, entrusted to a guest editor. Indeed, the first issue (Vol. 15, No. 1, March 1990) was a special issue edited by Heraklis Polemarchakis, with six papers focusing on "The Allocation of Risks in an Incomplete Asset Market". But, the following issues until 1995 published refereed unsolicited manuscripts on different risk and insurance themes. ${ }^{8}$ The next Special

\footnotetext{
${ }^{6}$ No 54 was devoted to professional liability insurance.

${ }^{7}$ Among them, two future Nobel Prizes: Robert Merton and Joseph Stiglitz.

${ }^{8}$ Since the beginning, the journal has also published each year an invited paper, due to a new initiative of The Geneva Association, "The Geneva Risk Economics Lecture" delivered on the occasion of the EGRIE meeting. The first of these lectures was delivered in 1989 at HEC-Paris by Kip Viscusi and published in Volume 15, No 2 (September 1990) as "Social insurance for work and product injuries."
} 
issue appeared only in June 1995 (Vol. 20, No. 1), focusing on "Non-Expected Utility and Risk Management" and co-edited by Christian Gollier and Mark Machina. With this issue, Christian Gollier replaced me as co-editor of the journal. ${ }^{9}$ Later, in 1998, my partner as co-founding editor of the journal, Harris Schlesinger, left his position, to be replaced by Neil Doherty.

The following important step in the history of the journal was the adoption of a new name. The Geneva Papers on Risk and Insurance Theory were renamed The Geneva Risk and Insurance Review. This occurred in 2005, on the occasion of a change in the distribution of the journal. ${ }^{10}$ Springer replaced Kluwer as publisher. Keith Crocker and Pierre Picard were in charge of editorship at that time.

Finally, note that The Geneva Risk and Insurance Review adopted a new colour, green, in September 2013. Michael Hoy and Achim Wambach were editors at that time, and the journal was published by Palgrave. ${ }^{11}$

Since the start, the journal has maintained the reputation Harris and I had intended to establish for such a publication. A highly selective journal publishing rigorous scientific articles leading to the advancement of a better knowledge of risk, uncertainty and insurance and of their role in the economy. Only a few articles each year, but reference articles.

\section{About the Author}

Henri Loubergé is Emeritus professor at the University of Geneva. He is a former associate editor of The Geneva Papers on Risk and Insurance and co-founding editor of The Geneva Papers on Risk and Insurance Theory.

${ }^{9}$ I remained "advisory editor" and co-edited with Marti Subrahmanyam an additional Special Issue in 1996 on "Insurance and Financial Risk Management" (Vol. 21, No 1, June 1996).

${ }^{10}$ Harris Schlesinger reminded me that the change in name was required by the SSCI (Social Science Citation Index). This institution did not want to list two different journals with roughly the same name.

${ }^{11}$ Note, however, that the copyright has remained with the International Association for the Study of Insurance Economics-The Geneva Association-since the beginning. 